\title{
Developing a Writing Course for Engineers at Vietnam Atomic Energy Institute Using Competence-based Approach
}

\author{
Pham Thi Thu Trang ${ }^{1}$, Duong Thu Mai ${ }^{2, *}$ \\ ${ }^{1}$ Vietnam Atomic Energy Institute, \\ 59 Ly Thuong Kiet, Hoan Kiem, Hanoi, Vietnam \\ ${ }^{2} V N U$ University of Languages and International Studies, \\ 01 Pham Van Dong, Cau Giay, Hanoi, Vietnam \\ Received 02 August 2016 \\ Revised 26 September 2016; Accepted 15 March 2017
}

\begin{abstract}
The strong needs of the working learners at Vietnam Atomic Energy Institute (VAEI), the urgent requirements of their jobs and ambitious expectations of the Institutes' authorities have given strong impetus to the designing of a special writing course for the learners. In relation to course designing, the use of competence-based approach has proved more effective than the other existing approaches in producing learning outcomes that can meet future staffing requirements of the institute. Based on the anslysis of VAEI contexts, the learners' needs and the employers' requirements, the paper explores the target genres, determines the specificity of writing competences covered within the course, and then develops a competence-based course schedule. Since this is the first attempt of its kind, the paper is expected not only to present a needed course for the engineers at VAEI but also to provide suggestions for course design and its implementation in the light of Competence-based Approach.
\end{abstract}

Keywords: Course designing, English for Special Purposes, writing course, competence-based.

\section{Rationale}

In the industrialized world, a great number of graduate who are expecting to gain more advanced knowledge and open access to the professional world and fit the high demands of employers need a strong English competence. Among the English competences that working learners seek training, achievement of English writing proficiency assumes an enormous importance. Nevertheless, second language writing tasks are extremely challenging and

\footnotetext{
Corresponding author. Tel.: 84-1669686968.

Email: duongthumai@yahoo.com
}

may be especially frightening to these working students. This is not only because different languages seem to have different ways of organizing ideas and structuring arguments but because students' prior writing experiences in the school, college or university do not prepare them for the literacy expectations of their professional workplace.

Due to widespread concern about the quality of students' learning process, particularly the fluency in the conventions of writing in English at work, and in response to increasing calls for learning outcomes upon course completion, Competence - Based 
Approach has originated. As a result, writing teachers and course designers are supposed not simply to develop the content of teaching writing generally but to recognise particular kinds of writing which are valued and expected in one certain professional context.

In the social context of Vietnam, a recent concern in equiping English competence for human resources in the nuclear field has been raised. Related to this strategy, Vietnam Atomic Energy Institute (VAEI), Ministry of Science and Technology, is a national research institute whose responsibility is to train and develop man power in the field of atomic energy - the field encompassing a plenty of international scientific studies and technological materials. In reality, most engineers working at VAEI has limited or unsystematic writing competence although they are aware of the need for improving it, their job requires them to use it nearly everyday, and their bosses mention its importance in all working agenda. Hence, building and maintaining the availability of a research workforce, who are competent in written English, has been one of the most critical challenges of VAEI. Notably, there have been no attempts in investigating this issue before, raising a call for an English for Occupational Purpose (EOP) writing course to be developed. This course with workplace orientation should be developed so that the learning outcomes can meet future staffing requirements of the nuclear organization. In this case, based on understanding of VAEI context, learners' needs and employers' requirements analysis, course designers are to explore the target genres, determine the specificity of writing competences covered within the course, and then build up course guides and schedules.

The aforementioned reasons have given rise to the the focus of this article, the development a writing course, in which competence-based approach is selected. The article would touch upon the theory and application of Competence - Based Approach in English Language Teaching, particularly in a workplace - oriented writing course, the theory and realization of
English writing competences, and investigate the foremost needs of targeted learners group and leaders' typical requirements for their staff's English writing competences. Also, a competence-based syllabus was designed with the most important components of a writing course. Hopefully, the article would shed some light in the area where resources are limited and the useful reference for course developers.

\section{Approaches in English language course designing}

The approaches in course designing, which have been characterized by the pedagogical tendencies, have been profuse and varied. More and more different trends have been evolved and formulated mainly in terms of diverse teaching methods, each of which has attempted to find more effective and efficient ways of teaching and learning. Hence, the aim of this part is precisely to review such merits and shortcomings of recent approaches to English language course designing. This effort will help to shed the light into the core of each selected approach, then determine which aspects of Competence - Based Approach can be considered to outweigh others when facing workplace settings or less academic situations in this "postcommunicative era" (Molina et al., [1]).

In the first place is skill - based approach (SBA). Advocates view the course content following SBA involves a collection of particular and seperated skills that may play a role in bridging skill gaps. Each skill is divided into subskills, which are gradually taught in a predetermined sequence through direct explanation, modeling and repetition. It is claimed that this approach can not only be easily implemented but enable the learners to acquire skills easier and satisfy their needs to some extent. Nonetheless, the course design in which isolated skills are taught that the brains can not store bits of information for a long time (Anderson, [2]). Additionally, the passive role of students and narrow skill - based instructions 
are said to lead to the underdevelopment of independent learning skills and competences.

The second noteworthy approach is contentbased instruction (CBI). It has been widely used in a variety of different settings such as English for Specific Purposes since the 1980s with the integration of targeted knowledge instruction and instruction in the content areas. The focus is thus on the substance or meaning of the content that is being taught. It advocates a claim that it leads to more successful programme outcomes than alternative language teaching approaches. Critics say that most language teachers have been trained to teach language as a skill rather than a content subject. For the students, they may feel confused, overwhelmed, or even frustrated. They may also have limited time to achieve an adequate academic level. Also, assessment is made more difficult, as both subject matter and language skills need to be taken into account.

Thirdly, theme-based instruction is one of the approaches within the broader model of CBI in which the emphasis is using the subject matter as the content of language learning. In ELT, it differs from traditional language instruction in that the language structures/items to be covered in a syllabus are determined by the theme or topic. In line with this, the theme or topic runs through everything that happens in the classroom and acts as a connecting thread for pupils and teachers; hence, effective theme-based instruction is extremely demanding for course designers in both planning and in implementation.

The next-to-last instructional approach which is spawned by Comunicative Approach is the Functional-Notional approach (FNA). Its main focus is explained on the concepts such as "time, space, movement, cause and effect" and "the intentional or purposive use of language" that learners need to communicate about (White, [3]). However, it is argued that FNA provides limited communication that could be achieved only in certain settings (Widdowson,
[4]). To sum up, the syllabus under FNA could be seen as an ideal way of teaching purposeful communication as long as all suitable circumstances are implemented.

3. Course development according to Competence - based approach

\subsection{Definition of competence and features of competence-based approach}

This term was defined as "the capacity to accomplish "up to standard" the key occupational tasks that characterize a profession" (Kouwenhaven, [5]). In like manner, competence was referred as output the ability to perform in work roles or jobs at a desired level or to a certain standard in employment (Field \& Drysdale [6]).

A competence based course should promote this definition of competence. Thereupon, the competences that should be developed by the end of the education programme is the criterion for arranging the course. More pariticularly, competences or a set of competences that are needed by a competent professional are supposed to be clearly defined, measurable, and related to the knowledge or skills needed for future endeavors, such as additional education or employment. Also, knowledges and skills were determined by competences are "domain specific". For each domain, a set of subdomains elaborate the specific competences that a student must demonstrate (Kouwenhoven, [5]).

One more essential feature is CBA addresses what learners are expected to do with what they learn. By all means, CBA is learnercentered and the individual worker is central. Based on his "competence status" or already acquired competences, the competences are defined that still have to be acquired and developed. Thereforth, objectives of the lessons or competencies to be acquired are stated via individual requirements. Objectives are broken into narrowly focused sub-objectives, 
so that both teachers and students can get a clear sense of progress (Richards, [7]).

Equally important, assessment is the integrated part in implementing the CBA in English Language Teaching which is considered not only in exams but also in an ongoing instruction. Also, it is implemented through criteria referenced assessment, which measure the achievement of each individual in the compared relation to standards, criteria, not by comparing learners with others (Chinh, [8]). Another key point in CBA is continuous feedback on the formation and development of their competences and the use of appropriately designed materials with competence (Chinh [8]).

Last but not least, the role of the teacher under CBA is that of a "cognitive guide" or a guiding role (Kouwenhoven [5]). Teachers encourage language learners to engage in active inquiry and make competencies visible. On the other hand, he added that the involvement of a teacher in the learning process moves students gradually to their self - regulation or gets them slowly used to independent learning.

That is to say, the course arrangement and how to convey knowledge in CBA support the development of competences. Moreover, the acquisition of knowledge takes place in the context of professional application. This requires fundamental changes in course design, including course designer's recognition about working learners and industry needs, the course context, the roles of students and teachers.

In a nutshell, CBA is indeed learnercentred, outcome-based and adaptive to the changing needs of students, teachers and the community. It deals with the demand to function or at least survive in society by using focus on the mastery of the performance rather than theory. The course is broken down into very specified objectives which are set based on the learner needs and the expected outcomes and through on going assessment. One application of CBA is CBLT which focuses "on language as a tool for communication rather than on language knowledge as an end in itself" (Nunan, [9]). Thus, CBLT learners' confidence is enhanced because they can achieve language competencies required in the performance in real life.

\subsection{Course development process according to competence - based approach}

As with Gustafson \& Branch [10], the five core elements in course development process encompass Analysis, Design, Development, Implementation, and Evaluation (ADDIE). Analysis often includes conducting a needs assessment, which includes input from students as well as from the various people connected to the course, such as teachers, funders, and employers (Graves, [11]). In order to conduct this assessment, course designers may use a variety of methods, including questionaires, tests and interview as common tools. After that, the goals focused on learners' needs are to be determined and stated.

The second stage is Design which needs to be specific with attention to details and the attainment of the course's goals. It includes writing objectives in measurable terms, classifying learning as to type, specifying learning activities, and specifying media. The third, Development consists of preparing student and instructor materials as specified during design (Kemp, Morrison, \& Ross, [12]). Then Implementation includes delivering the instruction in the settings for which it was designed (Greer, [13]). The last stage, Evaluation includes both collecting data to identify needed revisions to the instruction and to assess the overall worth of the instruction (Dick \& Carey, [14]).

As it can be obviously seen, the strengths found in ADDIE model are compatible with CBA in course designing. Initially, ADDIE and CBA are learner-centered, which means that the learner and his or her performance are the focal point of the instruction. In addition, employing ADDIE and CBA, course designers 
are expected to establish well-defined goals and break them down into very specified objectives which are set based on the learner needs and the real - world performance and through continuous and on going assessment. Related to the issue of performance, ADDIE is believed to be geared toward reliable and valid measurement of the skills and knowledge learners will be required to demonstrate in the real world. (Gustafson \& Branch, [10]). That is to say, ADDIE model should be made use of in course designing according to CBA.

\section{Developing writing course under competence - based approach for engineers at Vietnam atomic energy institute}

Within the framework of this paper, four out of five ADDIE elements, including Analysis-Design-Development-Evaluation, were applied into the process of writing course development using CBA. Needs analysis was an initial step to gather data and information about the foremost needs of VAEI working learners group as well as some VAEI leaders' typical requirements and expectations for their staff's writing competences in English. The data were then analysed to identify the essential and context - dependent writing competences for the purpose of course development and selection for Design and Development. Based on the specification, course designer recognized and determined five domains in course development, including course objectives, contents, activities, assessments and materials. Those domains are the most important and highly required in the sample of outcome-based course guide of Hanoi National University (Hướng dẫn xây dựng và hoàn thiện chương trình đào tạo theo chuẩn đầu $\mathrm{ra},[15])$. The last stage is Evaluation which made exploration into a group of teaching experts' opinions of the developed need-based writing course pilot using CBA for appropriate modification. In the scope of the minor thesis, the fourth stage of course Implementation was skipped and may be hopefully shed into light in another further research.

\subsection{Needs analysis}

Data collection instruments emloyed in collecting needs data were composed of a survey questionaire and a semi-structure interview protocol. Then two methods including graphical method and simple percentage analysis were applied for the questionnaire and content analysis for the interview data analysis.

\subsubsection{Needs from students' perspectives}

The initial stage was the delivery of the questionnaire whichdesigned to investigate the VAEI students' needs of a writing course's components, focusing on the target competences. The paper-based questionnaire were sent to 50 working learners at VAEI whose English proficiency level is B1 and higher. The job nature enabled the researcher to approach and directly work with the respondents from four main subsidiaries of VAEI, including Head Office, Institute of Nuclear Science and Technology, Institute for Technology of Radioactive and Rare Elements, and Non-Destructive Center. Due to four seperatedly locations, the survey was implemented in each subsidiary within 30 minutes while the researcher clearly presented about the aims, contents of the questionaire to the respondents. Also, the process of delivering and collecting the questionaires were tightly monitored. The students' queries were answered thoroughly to avoid misinterpretation leading to false identification. A known limitation of the sample for this study is that learners with English proficiency level below B1 were only included marginally. It was acknowledged that researcher's bias could have occurred when selecting participants. Response rates are very high in the questionnaire; the results will be presented in details in the following section.

From the received answers to the questionaire, there are some striking points that needs considering while designing the course. 
Initially, three competence-based objectives that students expected to obtain the most were "controlling the grammatical mistakes", "writing formal emails" and "writing journal articles". Secondly, the level of language proficiency that the majority of students aimed to achieve at the end of the course was B2. Among different genres of written documents, the most difficult those students predict to cope with was research paper. Two types of assessment were ranked at the top on the scale of importance as well as effectiveness on learning progress was "final assessment" and "teachers' assessment". In terms of teaching methods, the combination of "teachers' lecturebased" and "student-centred activities/tasks" were the most highly appreciated. The large percentage of students was ready to self-study at home twice as long duration as in class. About the lesson sequence, Pretask - Task Practice was supposed substantially effective. For students, the role "collaborators with teachers and peers" was strongly emphasized; whereas, for teachers, they were the roles "acitivity organizer" and "activity facilitator".

\subsubsection{Needs from employers' perspectives}

In addition, the semi-structured interview method was adopted to work out the employers' requirement to English writing competences of their engineers. All of them are PhDs graduating abroad and currently working for VAEI, have high frequency and experiences of dealing with English technical writing and international journalling.

The interview for 03 leaders involves the employers' requirements of English writing competence to their staff. To summarize, VAEI leaders shared their highest expectation that the engineers should attain the ultimate competences of journal article writing. Their emphasis were put on grammatical, scientific accuracy and the findings that one writing piece encompasses. Learning how to write through reading is the way highly recommended afterwards.
4.2. Designing course objectives and assessment scheme

Besides information from the needs analysis, one of the most visible writing constructs/competence models to base on is the The Common European Framework of Reference for Languages (CEFR), which is regarded as a key guidance for course designers in shaping the course objectives.

In terms of writing, the CEFR provides 'illustrative descriptors' presented as a series of scales with Can Do statements from levels A1 to $\mathrm{C} 2$. These scales can be used for writing syllabus designers, coursebook publishers and writing test providers worldwide, including Cambridge ESOL, seek to align their exams to the CEFR for reasons of transparency and coherence. It can be seen from the descriptors, users/learners bring to bear their capacities as detailed above for the realisation of written communicative competence, in narrow sense, including linguistic competences, sociolinguistic competences and pragmatic competences (Council of Europe, 2001) [16].

For linguistic competences in writing, CEFR clearly distinguished them into lexical competence, grammatical competence, semantic competence, orthographic competence. Semantic competence deals with the "learner's awareness and control of the organisation of meaning"; whereas, orthographic competence involves form of letters in printed and cursive forms in both upper and lower case, the proper spelling of words, including recognised contracted forms, punctuation marks and their conventions of use (Council of Europe, [16]).

With regard to sociolinguistic competences, the knowledge and skills required to deal with the social dimension of language use such as use and choice of address forms, newspaper headlines, proverbs, idioms, differences between varieties of language used in different contexts (Council of Europe, [16]). All of these vary in different contexts and from one culture to another. In respect of pragmatic 
competences, they are concerned with the user and learner's knowledge of the principles according to which written texts are organised, structured and arranged, used in communication for particular functional purposes such as description, narration, commentary, exposition, explanation, argumentation, persuasion (Council of Europe, [16]).

When it comes to the particular writing course design and writing assessment context of workplace for occupational purposes, CEFR appears to outweight other procedures. It can be adaptable to fit the context and central to the outcomes of learning which competence-based approach aims at. Once the context and purpose are established, it is possible to delineate the target language use situations and each TLU may suggest a different combination of skills and language exponents. Furthermore, demands may vary on different courses: those such as engineering may require higher levels of ability in literacy-related areas than others (Council of Europe, [16]). This is why CEFR descriptions were used to design the most important component of the targeted writing course: course objectives and assessment scheme.

\subsection{Developing writing teaching activities and materials}

Because of the hard nature of writing skill, engaging learners in writing in the target language is a tough job. As a result, different theories have emerged to provide teachers with a relevant ways of teaching writing, in which two of the most common are the product approach and the process approach.

According to the former approach, students are encouraged to mimic a model text, which is usually presented and analysed at an early stage. They also copy and finally transform the models into a new essay to be as perfect as the one that they have imitated by focusing on the language as instructed by the teacher. After that, students are required to submit their written essays to the teacher to be marked and graded rather than evaluated. Teachers in this perspective see errors must be corrected or eliminated (Tribble, [17]).

Meanwhile, in the latter approach, students need to move back and forth while going from one stage to another stage and take part in writing activities. During the activity, they may return to pre-writing activities even after reaching the final revising stage. In this process, the focal point is the writer and the writing process. The emphasis is on the linguistic skills of learners such as planning and drafting prior to linguistic knowledge like grammar and text structure. The teachers are facilitators who monitor the activities in various stages. On the other hand, in process writing approach, many models in process are used, but there are four interrelated activities involved - generating, organizing, composing and revising (Gregg \& Steinberg, [18]).

To design the writing teaching activities for reaching the targeted competences, the combining of both product and process approaches to writing teaching activities were chosen to assist student writers to enhance their skills in using the language by experiencing a whole writing process as well as gain knowledge from the model texts. Based on the orientation of targeted activities, the materials were thoroughly considered, selected and adapted correspondingly.

\subsection{Describing the initial writing course}

The 21-week course is designed to upgrade students' written English level from B1+ towards an adjusted B2 according to CEFR (Common European Framework of Reference). The course focuses on the development of Writing, a proficiency language skill which is integrated with the needs of students, the requirements of the employers and the study of prose models drawn from various sources.

The overall goal will be accomplished through the exploration of various written genres (e.g., emails, instructions of technical process, journal articles) and text types (e.g., description, journal abstracts, introductions 
sections, methods, and results, describing data and citing references). The course objectives and assessment scheme are based on CEFR Level B2 description, with adaptations to suit the actual teaching and learning conditions at VAEI. By the end of this course, students will have been able to demonstrate a number of language competences, including linguistic, pragmatic, strategic, orthographic, sociolinguistic competences. Each competence are described in the form of CAN DO statements. For instance, for linguistic competence, students are expected to have sufficient lexical repertoire in content areas namely Nuclear Science and Technology, Innovation and invention, Climate change, Uranium mining, Fuel manufacturing, etc.

In weekly schedule, three main components, writing objectives, learning materials and extra reading materials were stated correspondingly in the format of table. The column of writing objectives put the emphasis on the development of paragraphing, essay writing and journaling. Based on that, the assessment tasks such as regular mini-tests emphasizing grammar, class participation, exercises and essays, midterm test, portfolio, final examination and their marking weight were determined below the weekly schedule. Besides, the requirements of submission package were included. Students are required to hand in two 750-word essays and one journalling assignment of the given topics. On the other hand, participation and attendance policy of the course were figured out as well.

\subsection{Evaluating the developed writing course - Views of teaching experts}

After the first draft of the course was shaped, another step conducted was a semistructured interview to gain teaching experts' evaluation and recommendations about the drafted course. The interview was conducted with the participation of three experienced course developers, focusing on five fundamental questions which were raised on the basis of the second research objective - ascertaining experts' judgment on the course draft for the later judicious modification of the course. Three experts are all knowledgeable, prominent and renowned in the field of designing English language course in Vietnam. The consultation outcome is conferred as follows.

4.5.1. The appropriateness of the course objectives to students' language proficiency

According to the first draft of course guide, the objectives of the course "Writing course using competence-based approach for engineers" are based on CEFR B2+ Description and put emphasis on upgrading students' writing competences such as linguistic, pragmatic, strategic, orthographic control, sociolinguistic competences from B1 towards $\mathrm{B} 2+$. The ultimate outcome of students upon completing the course is emails, reports, and the project of journal article written by them.

To this question, most interviewees expressed their worries about the students' current language proficiency level which is not sufficient for them to obtain the final goal of the course (Interview 1). Accordingly, the fourth interviewee doubted that B2 description cover merely essay writing, and does not encompass the lattermost course outcome - writing journal articles. In other words, the course "aim" is too "high" at present (Interview 3). Likewise, the second expert claimed that the course loads comprising three different genres are too heavy and bulky. She added each genre requires varied writing competences and sub-skills. For instance, only one genre writing such as journal article certainly take a long duration of teaching and learning abstract, introduction, results, etc. Meanwhile, students definitely need to have developed their paragraphs and essay writing, even skillfully completed IELTS task 1 and task 2 already. In short, the course aim should be mainly determined by the current situation of VAEI learners's "needs and lack", instead of the leaders' expectation as a focal point. It is thought that in many cases, the requirements of managers are unreachable, "unfeasible" (Interview 2). 
Due to the above reasons, some adjustments were vigorously recommended by all experts. Firstly, the fourth one suggested adjusting the objectives into less complicated ones such as essay writing and merely "touching journal article writing", not focusing on completing the whole journal article. In another case, if the course aim remains unchanged, the prequisite of students' entry level should be B2 according to CEFR because only with B2 or higher level, students can deal with comprehensively reading documents of their subject matter; as a result, they will be able to use the "input" to apply in their writing (Interview 1). Simultaneously, in terms of target competence description, it is necessary to be more simplified, more apparent by "picking words" which can clarify and specify how to measure and where to realize the competences, instead of making use of the "ambiguous" words such as "good" (Interview 2). On the other hand, some stated objectives appear relevant to "oral production" and "oral interaction". A case in point is "express themselves clearly ... what they want to say in professional life" hence, their wording should be reconsidered and paraphrased to be more corresponding to written competences (Interview 3).

4.5.2. The completeness of the course content and materials

All the interviewed experts supposed that the designed course content covers relatively adequate targets towards B2 writing, even far more and heavier than $\mathrm{B} 2$, whereas the duration of 160 hours of face-to-face learning is only 20 weeks. There is much concern that the density of inclass learning may lead to working learners' pressure and ineffectiveness and time shortage for self-study (Interview 3). By the same token, the fourth expert added that time for self-study should be at least equal to class time, even double and clearly stated in course description. Thus, together with lowering the course aim as mentioned in 4.2.1.1., it would be better to lessen the whole class duration as well as reduce weekly inclass time, for example, 4 hours per week for face-to-face learning and 8 hours per week for self-study.

In addition, it was thought that the content should be condensed. There is no need to spend much time teaching different kinds of paragraphs but "teaching the sub-skills" to write a paragraph skillfully such as writing topic sentence, supporting sentence, paraphrasing (Interview 1 and 2). Subsequently, the next focused content should be essay types which are in need and frequently written in students' real work such as "cause and effect, problem-solution, advantage-disadvantages, argumentative". Those types are all believed to "match academic writing" and should be adapted to the course aim with "nuclear vocabulary input" (Interview 1). Ultimately, the course give students the "orientation" and "approaching" to writing each part of a journal article as an essay (Interview 4).

To support the course content, a list of core and supplementary materials were thoroughly examined and picked; hence, they are all highly appreciated by experts. However, more clarification is needed about "which page and chapter of materials" are used for each week, "what to do with the extra reading" and how it is "relevant" to the course (Interview 3). The reading may be taken advantage as the "input" provided to students for writing and widening their lexical repertoire of subject matter nuclear (Interview 1).

4.5.3. The coherence of course schedule and assessment scheme to the course objectives

The most remarkable point in most interviews is the design of course schedule in form of table, which makes it much clearer to the readers and examiners than just listing (Interview 1, 3, 4). Nevertheless, there are a number of comments about the input of contructed syllabus.

Firstly, due to the spreading and continual 20 week frame with heavy workloads, the second and fourth interviewees strongly recommended that the course should be divided 
into two separate but integrated "modules", in which first module is about "from paragraph to essay" and the second module is "from essay to journal articles". The time allotment for module 1 should be to thoroughly envisage and tend to be more than module 2 so that working learners can develop well-grounded knowledge, skills and competences in the first module before approaching higher objectives in the second one. Besides, they thought that in each module, two more columns, "content", "activities" should be added and "extra reading" will be replaced with "homework". In contrast, there should not include "writing a formal email" due to the communicative feature of emails which had better to be considered in another course (Interview 2). Obviously, the division, addition, omission and replacement were expected to make a great contribution to the schedule' coherence.

Secondly, "the input" of the schedule needs to be reconsidered and rearranged. For instance, the lesson "reviewing essentials of essay structure" takes place in week 1- several weeks before "sentence, clause, basic paragraph structure", which is unreasonable teaching sequence. Another case in point is the bullets in the column "objectives", some of which were supposed to inadequately demonstrate the column aim such as "vocabulary intensifying through extra reading materials" (Interview 3). The input of weekly "inclass activities" under the light of competence-based approach also needs to be specified (Interview $2 \& 4$ ).

Thirdly, about final assessement, the tasks were said to lack clarity and appropriateness to students' language proficiency level (Interview $3)$. In particular, the "length and requirements" of essay tasks are reaching $\mathrm{Cl}$ description according to CEFR, whereas the ultimate goal of the course is $\mathrm{B} 2+$. The exercises and portfolio are confusing with no details of which exercises mentioned and which paragraphs or essays expected in the portfolio package. Also, there is little information about the mid-term and final test such as format, assessment guide. As a result, plans of final assessment were suggested, for example, a "timed essay writing test" in class at the end of module 1 and a "final project - an article" submission for module 2 (Interview 4). Additionally, the second expert notified that marking scheme for essay based on competence approach is highly evaluated owing to its comlexity, but its details should be delivered to students and interpreted by them at the beginning of the course for their preparation and attempts in reaching the highest.

On the other hand, during the study process, how to feedback was mostly concerned. One of the common types in writing is "peer check"; however it may be ignored if working learners are not interested in it and limited in language proficiency and peer check skills. On the contrary, teacher's feedback plays a vital role in supporting students, thus, " a guide or form of feedback" should be included in course guide to illustrate teacher's help (Interview 1).

4.5.4. The integration of teaching methods, teachers and students' roles

All experts proposed the teaching methods according to competence-based or "performance-based approach" that is concerned about not only what students know but what they are able to do as result of classroom instruction. It assumes that students learn information and perform essential skills when they are given sufficient time and support. Teachers at all levels, have the responsibility for devising instructional procedures through which their students achieve desired learning outcomes. In short, the methods is claimed to focus on students "demonstrating what they have learned", thus teaching requires "realistic and authentic class activities". Yet, the interviewees also noted about "training teachers" of the course not only in terms of subject matter, but also how to give instruction and feedback, how to implement authentic class activities so as to encourage all students to attain these goals.

4.5.5. The success probability of course implementation 
The number of positive views on successful course implementation is relatively large. The first reason is the facilitation of VAEI managers and the "high and urgent demand of learners at $V A E I$ " for writing competence in occupational context, regardless of the course' difficulty and pressure. Furthermore, the "prequisite proficiency level of students" for joining the course is at least B1 before Module 1 and beginning B2 before Module 2 (Interview 2, 3). It can be seen that the entry level of learners is rather high, thus they are expected to be "active" and "hardworking" in English language. The time allotment after thorough consideration of "reducing class time density" is promising in providing students with "sufficient time" to absorb the instructions and acquire the competence to be active and independent users of language writing (Interview 1, 4).

\subsection{Decisions on editting the $1^{\text {st }}$ course guide}

After analyzing the interview data, some decisions have been made towards revising the targeted writing course.

\subsubsection{Course objectives}

The initial course aim of writing a complete journal article and beyond upon the end of the course was found to be out of reach to the working learners whose language proficiency entry level is minimum B1 according to CEFR. Therefore, it is necessary to lower and simplify the objectives to occupational essay writing and touching the components of writing journal article. The wide range of relevant subject matter, nuclear vocabulary which was targeted earlier also need to be reconsidered by picking a number of significant and must-known topics of nuclear and exploiting their lexical items during the course such as climate change, greenhouse effects, nuclear power, nuclear energy, fuel manufacturing. Accordingly, the originally stated competences are specified and reworded to be more corresponding to the ultimately editted goal.

\subsubsection{Course content and materials}

Some comments emphasized on the densely arranged and nonstop inclass learning thoughout 20 weeks of the course. Hence, it sounds more reasonable to include only 4 hours of face-to-face learning per week and suggest 8 hours of self-study. With the editted weekly class time, the whole duration will be lengthened to 30 weeks or more, instead of 20 weeks. This brings hope that working learners can manage time to absorb knowledge, skills, tranfer them into the written products and finally attain the targeted competences.

One more important thing is the new course's content are supposed to focus on the competences of paragraphing and essay writing which is applicable and adaptd to match VAEI occupational context. Then based on that, writing each part of a journal articles will be made more feasible by the approach and selectively instructions to suit learners' language capacity. As a consequence, the materials which are employed will be given in details in terms of specific pages, chapters and books. In addition, the large amount of supplementary reading will be diminished and clearly stated about what students need to do with it.

4.6.3. Course schedule and assessment scheme

To ensure the coherence of the course schedule, it will be seperated into two modules, each of which requires different students' writing proficiency entry levels, at least B1 for Module 1 and beginning of B2 for Module 2. The course policy which is relevant to testing students' writing entry competences will be tightly and strictly considered. On the other hand, the content, objectives, materials, homework and activities will be added to each module so that teaching methods, teacher's and students' roles can be clarified under the competence-based approach.

Furthermore, the tasks for assessment during the course will be reconsidered and suggested, one inclass essay task for final test of Module 1 under time pressure, and a final 
project of a journal article submitted at the end of Module 2. Simultaneously, the proposed marking scheme is decided to be mostly changed and shed the light on the word "good". It is supposed to be eligible and applicable for assessment but provide the necessary flexibility to the evaluators. Moreover, the form of teacher's feedback will be included in the editted course guide to give clearer orientation to teacher's feedback. The peer check will be omitted due to the learners' unwillingness and lack of peer check skills.

To summarize, the course objectives, content and schedule are of great significance for consideration and adjustments. It was skeptical that the initial course aim of writing a complete journal article for publishing was too high and sounded unreachable for students who are supposed to hold B1 proficiency level. Therefore, it needs to be moderated to feasible objectives such as writing from paragraph to essay and then from essay to touching each part of a journal article. Secondly, it was necessary for the input of weekly schedule to be selected, added and rearranged to ensure the coherence of modules and content such as seperating weekly writing objectives, activities, materials and homework. As a consequence, the time allotment was asked to be reconsidered. Last but not least, the assessment scheme was highly appreciated but still required to get more details and appropriateness of assessment tasks for each module. Based on those evaluation date, the revision involving making needed changes has been decided and formed the editted course guide.

\section{Conclusion}

On the basis of the comments and ideas of people related to the course such as students, employers and teaching experts, several recommendations for designing a competencebased writing course are figured out.

Firstly, to conclude the students' lack of language profiency in terms of writing competence and determine their current level, it would be better to implement a writing test at VAEI for those who desire to pursue the future course. This test result will be used to consider whether learners have prequisite conditions to take part in the course or not.

Secondly, with the working learners who pass the entry test and attend the course, it is essential for VAEI to produce course policy which is integrated with learners' benefits at workplace. For instance, in case learners achieve the ultimate course goal, they deserve being sent abroad for conferences, seminar, or further training. This type of policy may create the motivation, inspiration and even commitment to the students while participating the course.

Thirdly, VAEI and ULIS may establish and intensify the cooperation in terms of training a limited number of teachers who can be experts in writing teaching as well as master in nuclear field. Those who are selected should be thoroughly examined about their speciality to become English for Nuclear Purposes teachers.

Fourthly, once the course is implemented in reality, it is of great significance to obtain frequent feedback from learners and teachers, determine the training needs for appropriate and updated training policy, and meet the needs of relevant parties.

\section{References}

[1] Molina, G. T., Cañado, M. L. P. \& Agulló, G. L., Current Approaches And Teaching Methods. Bilingual Programmes. Granada: TEFL in Secondary Education, Editorial Universidad de Granada, 2005.

[2] Anderson, G. S., A Whole Language Approach to Reading. Lanham, MS: University Press of America, 1984.

[3] White, R. W., The ELT curriculum. Oxford: Basil Blackwell, 1988.

[4] Widdowson, H. J., Teaching Language as Communication. Oxford University Press, 1979.

[5] Kouwenhoven, W., Competence-Based Curriculum Development In Higher Education: A Globalised Concept. The Netherlands: VU University Amsterdam, 2003. 
[6] Field, L. \& Drysdale, D., Training For Competence: A Handbook For Trainers And Teachers. London: Kogan Page, 1991.

[7] Richards, J. C., Curriculum development in language teaching. UK: Cambridge University Press, 2001.

[8] Chinh, C. D., Teaching on Competency - Based Approach at Technical Education Universities, Phylosophy Doctor Thesis, Vietnam National Library, 2012.

[9] Nunan, D., Standard-based approaches to the evaluation of ESL instruction. International Handbook of English Language Teaching, 15 (2007), 421-438.

[10] Gustafson, K. L. \& Branch, R. M., Survey of Instructional Development Models. New York: Eric Clearing House on Information \& Technology, 2002.
[11] Graves, K., Teachers as Course Developers. New York: Cambridge University Press, 1996.

[12] Kemp, J., Morrison, G., \& Ross, S., Designing Effective Instruction (2 ${ }^{\text {nd }}$ Ed.). New York: Merill, 1998.

[13] Greer, M., The project mangager's partner: A step-by-step guide to project management. Amherst, MA: HRD Press, 1996.

[14] Dick, W. \& Carey, L., The Systematic Design Of Instruction (4 ${ }^{\text {th }}$ Ed.). New York: Harper Collins, 1996.

[15] Đại học Quốc Gia Hà Nội, Hướng dẫn xây dựng và hoàn thiện chương trình đào tạo theo chuẩn đầu $\mathrm{ra}, 2010$.

[16] Council of Europe, Using the CEFR: Principles of Good Practice. University of Cambridge, 2001.

[17] Tribble, C., Writing. New York: Oxford University Press, 1996.

[18] Gregg, J. \& Steinberg, E.R., Cognitive in applied Education. Oxford: Oxford University Press, 1985.

\title{
Phát triển một khóa học viết cho kĩ sư tại Viện Năng lượng nguyên tử Việt Nam (sử dụng cách tiếp cận dựa trên năng lực)
}

\author{
Phạm Thị Thu Trang ${ }^{1}$, Dương Thu Mai ${ }^{2}$ \\ ${ }^{I}$ Viện Năng luợng Nguyên tử Việt Nam, 59 Lý Thuờng Kiệt, Hoàn Kiếm, Hà Nôii, Việt Nam \\ ${ }^{2}$ Trường Đại học Ngoại ngũu, ĐHQGHN, số 1 Phạm Văn Đồng, Hà Nội, Việt Nam
}

Tóm tắt: Xuất phát từ nhu cầu mạnh mẽ của người học hiện đang công tác tại Viện Năng lượng nguyên tử Việt Nam (Viện NLNTVN), những yêu cầu bức thiết trong công việc và kì vọng lớn của các lãnh đạo Viện, việc thiết kế một khóa học Viết dành riêng cho các kĩ sư trong Viện ngay lúc này trở nên rõ ràng và cần kíp. Song song với đó, để kết quả đào tạo và bồi dưỡng có thể đáp ứng những đòi hỏi về nhân lực trong tương lai của tổ chức, việc sử dụng cách tiếp cận dựa trên năng lực đã và đang chiếm ưu thế hơn so với những cách tiếp cận khác trong mảng thiết kế khóa học. Theo đây, căn cứ vào bối cảnh của Viện NLNTVN, những phân tích yêu cầu của lãnh đạo Viện và nhu cầu của người học trong Viện, bài báo này hướng đến việc nghiên cứu một số thể loại bài viết đặc thù nhằm phục vụ công việc, xác định những năng lực viết cụ thể mà cán bộ Viện cần phát triển và sẽ bao gồm trong khóa học; từ đó, phát triển một chương trình khóa học với cách tiếp cận dựa trên năng lực. Một điều đáng chú ý là chưa có bất cứ nỗ lực nào trong việc nghiên cứu vấn đề này trước đây. Do đó, hy vọng rằng, bài báo không chỉ đưa ra một khóa học cần thiết cho các kĩ sư tại Viện NLNTVN mà còn gợi mở về việc thiết kế và triển khai khóa học theo đường hướng tiép cận dựa trên năng lực.

Từ khóa: Thiết kế khóa học, Tiếng Anh cho những mục đích cụ thể, khóa học Viết, tiếp cận dựa trên năng lực. 